IRSH 66 (2021), pp. 23-40 doi:10.1017/S002085902 I000109

(C) The Author(s), 202 I. Published by Cambridge University Press on behalf of the Internationaal Instituut voor Sociale Geschiedenis

\title{
Remembering the I 977 Bread Riots in Suez: Fragments and Ghosts of Resistance
}

\author{
Nayera ABdelRAhMAN SOLIMAN \\ Freie Universität Berlin \\ Berlin 14195, Germany \\ E-mail: nayera.ar@gmail.com
}

AвSTRACT: Most of the existing literature on the 1977 Bread Riots focuses on the protests as an episode in larger national and international political and economic waves of change, either as the end of an era of political mobilization in Egypt, or the beginning of an era of anti-neoliberal struggles in the region and wider world. Moreover, most of the literature focuses on Cairo. Seeking to diverge from the trend even further, this article focuses on the memory of the I977 uprising in the city of Suez, which it explores through the perspectives of leftist activists and others. It aims to understand how the people of Suez who witnessed and participated in the 1977 protests remember and interpret the event today, asking what memory of the uprising means politically on a local level. By exploring the memory of the 1977 protests in Suez, this article traces their effects on the lives of the selected interlocutors, and also on their political actions and interpretations. It follows three memory fragments of the 1977 protests in Suez from three different vantage points: the position of people who were members of political organizations before the protests; the traces of protests in Suez's streets; and the position of those who witnessed the protests from home.

On 25 January 1977, the front page of the prominent Egyptian newspaper Al Abram (Figure I) announced, "the arrest of a student cell headed by a teacher in Suez". The main headline proclaimed the capture of documents that proved members of a secret communist organization had planned the fires that erupted across Cairo on I8-i9 January I977. On I7 January, the Deputy Prime Minister for Financial and Economic Matters, Dr Abdel-Moneim El-Qaissouny, gave a speech in front of the People's Assembly, the lower house of the Egyptian parliament, in which he announced the imposition of economic austerity measures, including substantial cuts to government subsidies on select essential goods. ${ }^{2}$

I. Al Abram is one of the main official newspapers in Egypt, founded in I875.

2. Ahmed Seddik Saad, حاجتنا الي استر اتيجية اشتراكية جديدة [Our Need for a New Social Strategy], 2008. Available at https://modernization-adil.blogspot.com/2008/I 2/blog-post_9762.html; last accessed 2 January $202 \mathrm{I}$. 




Figure I. Front page, Al Abram newspaper, 25 January 1977.

The price of bread, sugar, tea, cooking oil, and rice would rise by between twenty-five and fifty per cent. He described these measures as prerequisites for receiving funds from the International Monetary Fund (IMF) and World Bank. The decision was announced in newspapers and on the radio on 18 January as "proposed" measures, though they were actually an executive order that took effect immediately, and prices increased that same day. ${ }^{3}$ Protests against the austerity measures in Cairo started with workers from the city's industrial southern suburb of Helwan, ${ }^{4}$ who were soon joined by students and other social groups. ${ }^{5}$ Meanwhile, simultaneous protests sprang up in other major Egyptian cities, namely, Alexandria, Suez, Mansoura, Qena, and Aswan.

Most of the existing literature on the 1977 Bread Riots focuses on the protests as an episode in larger national and international political and economic waves of change, ${ }^{6}$ either as the end of an era of political mobilization in Egypt,

3. Ibid.

4. As part of Nasser's industrialization policy in the I950s, a large industrial complex was built in Helwan, including steel, iron, textile, and cement factories.

5. Hossam El-Hamalawy, “i 977: The Lost Revolution” (Master's thesis, American University in Cairo, 200I).

6. At the international level, both in press coverage and scholarly works, Egypt's January 1977 protests, known as the Bread Riots, have come to be considered one of the first anti-IMF protests. 
or the beginning of an era of anti-neoliberal struggles in the region and in the wider world. ${ }^{7}$ Moreover, most of the literature focuses on Cairo. In one of the few studies of the 1977 protests that breaks with this Cairo-centric trend, Henry (2018) draws on oral accounts of leftist activists to trace the "treasure" of revolutionary experience and its transmission between three revolutionary events in Alexandria, including the 1977 uprising. ${ }^{8}$

Seeking to diverge from the trend even further, this article focuses on the memory of the 1977 uprising in the city of Suez, which it explores through the perspectives of leftist activists and others. It aims to understand how the people of Suez who witnessed and participated in the 1977 protests remember and interpret the event today, asking what memory of the uprising means politically on a local level. Over the course of a two-month stay in the city in 2018 , I asked numerous inhabitants, all of whom could be characterized as middle class by Egyptian standards, ${ }^{9}$ how they remembered the 1977 protests in Suez. Where did their memory of the protests start? What stands out in their memory? How do they interpret these events more than forty years later?

The protests were among the biggest seen in Egypt since the July 1952 revolution/coup, ${ }^{\mathrm{IO}} \mathrm{Suez}$ was not an exception in this matter. Public and private buildings were attacked and burnt, as well as buses and cars. In response,

See: A.C. Drainville, “The Moral Economy of Global Crowds: Egypt 1977, Brazil 2013”, New Global Studies, 9 (2015), pp. 101-124.

7. At the national level, the protests became the subject of much analysis regarding the role of

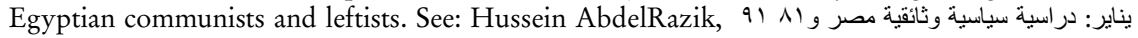
(Egypt on I8 and I9 January: A Documentary Political Study) (Cairo, 1984); Saad, "Our Need for a New Social Strategy"; Hossam El-Hamalawy, "1977: The Lost Revolution”.

8. Mélanie Henry, "Le "trésor" révolutionnaire. Insurrections et militantismes à Alexandrie en I 946 et I977, Égypte” (Ph.D., Université D’Aix-Marseille, 2018).

9. This paper is based on oral history interviews conducted with five men and one woman in Suez between November and December 20 I 8. Two men were part of a political organization during the I 977 protests. One was a teacher and the other was starting his career in a governmental institution. Two men who witnessed the 1977 protests in the streets were not part of a political organization, but were close to the local political elite. One participated in the protests, was a government employee and son of a famous local public figure. The other was the son of a famous butcher in Suez and working at a hotel. The last two witnessed the 1977 protests from their homes. The woman was a teacher. The man was a teenager and the son of a government employee. All my interlocutors belong to what we could call the middle class in Egypt, those who work in the public sector or own a small business. As doing fieldwork in Egypt became progressively more difficult and insecure, I was unable to extend my interviews beyond a secure and trusted network of interlocutors. Most of the names have been changed for the privacy of my interlocutors.

I0. On 23 July 1952, a group of Egyptian Army officers calling themselves the "Free Officers" seized power by force in Egypt after years of popular resistance against the British occupation in the Suez Canal region, which exercised significant influence over the government in Cairo, including the king and the political elite. This "coup" was supported by protests, hence many Egyptians refer to it as a revolution. Gamal Abdel Nasser established power by 1954, becoming an idol for his promotion of an anti-colonial, pan-Arab nationalist discourse until Egypt's defeat in the Six Day War in 1967. 
Sadat ordered the army to intervene to quell the unrest. On the night of i9 January, he imposed a curfew and revoked the controversial austerity measures. ${ }^{\text {II }}$

Suez had a special history related to the Arab-Israeli wars between 1967 and 1974. The "teacher" from Suez mentioned on the front page of Al Abram taught philosophy in one of the city's schools after the inhabitants of Suez were finally allowed to return from their forced migration in the late I960s and early i 970 s. In the aftermath of the Six-Day War in June 1967, around two thirds of the Suez population had been ordered to leave the city and relocate to other villages and cities around Egypt. ${ }^{\mathrm{I2}}$ Located on the war's front line, Israeli forces stationed on the east side of the Suez Canal attacked the city several times. On 24 October 1967, the Israeli Air Force bombed the city's petrol factories, setting Suez ablaze. As fires raged throughout the city, the Egyptian government ordered civilians to evacuate. Women, children, and elders, and also factories and their workers, were transferred elsewhere. ${ }^{13}$ Defying the order, however, many young men and women decided to join the fida'yyin (popular resistance) and stay in the city, along with a small number of state employees left to run the few remaining governmental institutions. ${ }^{14}$ For seven years, Suez was almost vacant.

When conflict erupted with Israel on 6 October 1973, the city of Suez endured a IOI-day siege lasting from October I973 to January I974. While Egypt considers itself to have won the war, marking its victory annually on 6 October, the city of Suez celebrates a different date: 24 October, which Suezis (the people of Suez) view as "the epitome of popular resistance prevailing over an invading military". ${ }^{\text {is }}$ In her research on the poems and songs of Wilad Al Ard (Sons of the Land), an artistic troupe founded by Suezis in I967, Alia Mossallam shows how they sought to keep "the struggle in Suez alive in the consciousness of the rest of the country". ${ }^{16}$ She argues that some of these songs were a medium for representing Sawayssa (Suezi) stories of resistance, which remain underrepresented in the state's official narrative of the 1973 war, according to which the military played the primary role in the fighting. ${ }^{17}$

I I. Saad, "Our Need for a New Social Strategy".

I 2. Mohamed Abdel Shakur, Sohair Mehanna and Nicholas S. Hopkins, "War and Forced Migration in Egypt: The Experience of Evacuation from the Suez Canal Cities 1967-1976", Arab Studies Quarterly, 27 (2005), pp. 22-23.

I3. Hamid Hasab, والنتصار الحصار المقاومة، :مدينة تجربة السويس (Suez: The Experience of a City: The Resistance, the Siege, the Victory] (Cairo, 200I), pp. 32-39.

I4. Ibid.

I 5. Alia Mossallam, "Hikāyāt Sha'b: Stories of Peoplehood. Nasserism, Popular Politics and Songs in Egypt 1956- 1973” (Ph.D., The London School of Economics and Political Science, 20I 2), p. 207.

16. Ibid. p. 2 Iо.

17. Ibid. pp. 222-248. 
When I visited the city in $2018,{ }^{18}$ residents told me that Suez was the last of the three cities along the Suez Canal to be opened so its inhabitants could return. Only in 1975 were Suezis able to go in and out of the city once again without permits. According to the 1976 census, the population of Suez stood at around 193,000 inhabitants, compared to 264,000 in 1966, ten years earlier, ${ }^{19}$ in stark contrast to the general upward trend in Egyptian population growth. Thus, when the protests against the government's austerity measures broke out in October 1977, Suezis were still coming back from their host villages and cities after seven years of forced migration (tahgir) and Suez was still under reconstruction. Infrastructure had not yet been redeveloped and the conditions of everyday life were unstable. Importantly, however, memories of the city's wartime resistance efforts were still present. The story of how the fida'yyin fought and died to protect Suez from the Israeli invasion was dominant in the collective memory of most of my interlocutors.

In focusing on "memory" in this article, I mean both individual and collective memory. According to Boyarin, "[m]emory cannot be strictly individual, inasmuch as it is symbolic and hence intersubjective. Nor can it be literally collective, since it is not superorganic but embodied". ${ }^{20}$ By exploring the memory of the 1977 protests in Suez, this article traces their effects on the lives of my interlocutors, but also on their political actions and interpretations. This is what Charles Tilly defines as the politics of memory, which is both "(a) the process by which accumulated, shared historical experience constrains today's political action and (b) the contestation or coercion that occurs over the $[\ldots]$ interpretation of that historical experience". ${ }^{2 \mathrm{I}}$

In exploring memory, I also draw on Gyanendra Pandey's concept of "fragment", which he describes in the context of studying history with two-fold meanings as "not just a 'bit' - the dictionary's 'piece broken off' - of a preconstituted whole. Rather, it is a disturbing element, a 'disturbance', a contradiction shall we say, in the self-representation of that particular totality and those who uncritically uphold it." ${ }^{22}$ Working with this concept of fragments helps

I 8. This trip comprised one of two fieldwork trips (one in 2017 and this one in 20I 8) for my Ph.D. research on the memory of forced migration in Suez in the aftermath of the I967 Six Day War. During these trips, I conducted oral history interviews with thirty-seven interlocutors (fourteen women and twenty-three men). Most of them were former or current governmental employees, though a few were business owners. A small number of the women were housewives whose husbands did not have fixed jobs or were farmers.

19. "Population Census 1976. Detailed Results, Suez Governorate”, Central Agency for Public Mobilization and Statistics, I978, p. I4.

20. Jonathan Boyarin, "Space, Time, and the Politics of Memory", in J. Boyarin (ed.), Remapping Memory: The Politics of Timespace (Minneapolis, MN, I994), p. 26.

2 I. Charles Tilly, "Political Memories in Space and Time", in J. Boyarin, Remapping Memory, p. 247.

22. Gyanendra Pandey, "Voices from the Edge: The Struggle to Write Subaltern Histories", Ethnos, 60:3-4 (1995), p. 238. 
us to acknowledge and consider the "fragility and instability of the 'givens' (the 'meaningful totalities') of history". ${ }^{23}$ Therefore, I follow three memory fragments of the 1977 protests in Suez from three different vantage points: the position of people who were members of political organizations before the protests; the traces of protests in Suez's streets; and the position of those who witnessed the protests from home. I argue that these three memory fragments of the 1977 protests show a specific temporality for those who were members of leftist political organizations in Suez before the protests that differs from mainstream literature and discourses on the 1977 event. They also help us to follow the material traces of faceless participants in the streets of Suez, as if following the traces of ghosts. These faceless participants are ghosts not just in the sense that they are invisible, but because a ghost has "real presence and demands [...] your attention". ${ }^{24}$ Everyone in Suez spoke about this presence - of the "protesters" - remembering what they did, what they burnt, and what they looked like. Yet, all my interlocutors insisted that they themselves were not among "them"; no one knew exactly who the protesters were. They were subjected to taghyib, a concept developed by the Syrian writer Yassin Al Haj Saleh that describes a process by which people are actively made absent in public space, encompassing the impossibility that they might be able to represent themselves. He argues that the vast majority of people in most countries, even democratic ones, are subject to this process. However, he adds that "the stranger or the 'subaltern' is not present unless she breaks into the theater and creates trouble". ${ }^{25}$

The memories of the 1977 protests in Suez are memories that "disturb what we think we know", ${ }^{26}$ offering the possibility to fill gaps in our knowledge of what happened during these two momentous days in Egyptian history, particularly in Suez. Moreover, I argue that they are "memories that haunt". ${ }^{27}$ By haunting, Salem means "how the legacies of some projects continue to have aftereffects, but not always in visible or measurable ways". ${ }^{28}$ Memory of the 1977 protests is attached to an immeasurable, omnipresent legacy of resistance in the city of Suez. However, it is also a memory of chaos and fear of the unknown. It is a memory among other memories in the city that relates to a period when Suez was still recovering from years of war, resistance, and destruction.

23. Ibid., p. 239.

24. Avery F. Gordon and Janice Radway. Ghostly Matters: Haunting and the Sociological Imagination (Minneapolis, MN, 1997), p. xvi.

25. Yassin Al Haj Saleh, التفكير إلصالح أفكار :الغانيبن أصوات (Voices of the Absent: Ideas Towards the Renovation of Thought), Al Jumburiya, 2 April 2020. Available at: https://tinyurl.com/ Is 8 hded I; last accessed is February $202 \mathrm{I}$.

26. Roberto Roccu and Sara Salem, "Making and Unmaking Memories: The Politics of Time in the Contemporary Middle East", Middle East Critique, 28:3 (2019), p. 223.

27. Ibid.

28. Ibid., p. 262. 


\section{EXTENDED TEMPORALITY: I 977 PROTESTS FOR POLITICAL ORGANIZATION MEMBERS IN SUEZ}

When I asked Mostafa Abdel Salam, the teacher mentioned in Al Ahram, about the 1977 protests, he started with: "when we came back to Suez after I974, a public movement was founded in Suez headed by a group of young people who belonged to a sub-movement in the Egyptian communist movement named the Al Tayyar Al Thawry [the revolutionary movement]". ${ }^{29}$ He went on to explain: "These movements were founded after the selfdissolution of the communist political parties", ${ }^{\circ}$ also commenting that "[t]hey didn't join either the vanguard organization or the Socialist Union". ${ }^{31}$ Mostafa and the two other colleagues of his I interviewed did not participate in the protests; yet, the authorities accused them of organizing the protests, with some of them also accused of burning buildings in Suez. For the members of Al Tayyar Al Thawry in Suez, the memory of the 1977 protests in the city begins with their activism there after the population's return. In this sense, the 1977 protests comprise not only the two days of riots in January, but also what they were doing both before the protests and after.

After the city's inhabitants returned, almost all my interlocutors recalled that Suez was full of rats. Many reasons were given for this phenomenon: the houses that had stood empty for more than seven years; the trash discarded from ships; the corpses during the war; and even a conspiracy theory that the Israelis had left them before finally departing from Suez after their IOI-day siege of the city in $1973 .{ }^{32}$ The members of Al Tayyar Al Thawry met a United Nations expert, who declared that Suez would soon be overrun by pests if the rats were not contained. Under the leadership of Hussein, younger than Mostafa but more experienced in community organizing, young men and women from Al Tayyar Al Thawry went door to door offering the residents pesticides, along with instructions on how to use them and other hygiene tips.

The group members also offered free tutoring classes for pupils in schools. According to Mostafa, he was called before one of the authorities in the city and told to stop the classes or to start charging money for them, because the authorities did not want the group to gain a reputation and influence among

29. This name was given to them by the authorities. They were a secret group that became more active after Egypt's defeat in 1967 and they were influenced by Maoist ideology. The group had members all over Egypt.

30. In 1955, the Egyptian Communist Party was dissolved and many of its members joined the Socialist Union as a reaction to Nasser's socialist policies; for more details, see Nadia Fawzi "Summary of the History of the Communist Movement in Egypt", Idaa't, 2 March 2017. Available at: https://www.ida2at.com/brief-history-of-the-socialist-movement-in-egypt/; last accessed 19 December 2020; and Gervasio, Gennaro, Al-Haraka al-Mārkisiyya fi Misr, I967198I (The Marxist Movement in Egypt, I967-198I), (Cairo, 2010).

3I. Interview with Mostafa Abdel Salam, Suez, 3 December 2018.

32. Interviews with many interlocutors in Suez, November-December 2018. 
the inhabitants. He refused, and they continued to conduct their free classes. It is also important to note here that Suez was still under reconstruction and its infrastructure was not fully functioning, including its schools. The group supported the leftist and progressive candidates in the local assembly elections of 1976. When two of the candidates succeeded, they continued to work with them closely. Mostafa and the other two colleagues I interviewed were young men in their twenties and thirties at the time, enthusiastic to be engaged in their local community after seven years away from their city, to which they were attached and had been longing to return. Their activities were visible in Suez's almost-empty streets and they were known to people in specific neighbourhoods. They were also known to the authorities as leftists or communists. Therefore, they were the first to be accused by the authorities of organizing the I 977 protests, as was the case for communists in all Egyptian cities following the Bread Riots.

On I 8 January 1977, Mostafa woke up at 9 am in his shared flat located in the heart of Suez's downtown to the sound of protests:

I went to the local assembly, where I met with the members and discussed the situation. They said there had been an incident at the police station in Al-Arba'in and another at the cultural centre. I committed a serious mistake in that I went with a friend to check on the cultural centre. The State Security took this as evidence and investigated us, accusing me of burning it. ${ }^{33}$

Mostafa and his fellow members of Al Tayyar Al Thawry told me they had not known about the protests before they happened. They said they went to the streets only to observe. Allam, a friend of the group, was employed at a hotel on Orabi Street at the time, which was one of the main streets in Al-Arba'in where the protests occurred. He witnessed a major part of the protests because the hotel was so central, and also because he had to help a friend who had been shot. He was summoned to State Security on the day of the protests and asked about another friend who belonged to the Tagamoa' (Assembly) party. ${ }^{34}$ There, Allam saw the names of his friends on a note in front of the officer. He warned the rest of the group. Initially, some of them said that nothing would happen, but by the end of the day, they had decided they had to escape from Suez in order to avoid arrest. They had to leave their city again, and with it their dreams. They hid for a few months in houses in Cairo, relying on secret means of communication. Eventually, they were cleared of all the accusations against them, as were most of the leftists from other cities who were caught up in the protests. ${ }^{35}$ Most of them returned to Suez. However, Mostafa's professional trajectory was directly affected. The

33. Interview with Mostafa, Suez, 3 December 2018.

34. One of the main leftist political parties in Egypt.

35. They remained in hiding for a few months, until they learned that the charges against them had been dropped, after which they gradually returned to Suez. The final verdict in which the rest of 
decision was made to send him to teach somewhere else, but he refused to move. As a result, he lost his job.

The 1977 protests directly affected the personal lives of this group, as well as their political activism. After 1977, the Sadat regime became more repressive against any form of activism, especially that of leftists and communists. On 3 February 1977, a law was issued to limit many democratic political rights. ${ }^{36}$ After this event, Sadat ordered police reinforcements, reluctant to ask the army for help again, as he had been forced to do in response to the January Bread Riots. ${ }^{37}$ For Mostafa and his colleagues, the 1977 protests represented the end of an era for potential openness in the political sphere, with the prospect of more freedom for political participation and more spaces for public activities. After escaping arrest and facing the closure of public space, the group was dismantled, as they could no longer get together to meet as they once had. For this group of activists, the memory of the 1977 Bread Riots in Suez includes far more than the two days of protests in January. It includes months of activism in a post-war city, the trials of escaping arrest, and induced changes in their personal, professional, and political trajectories.

This memory fragment shows a prolonged temporality of the events associated with the Bread Riots of I8-19 January 1977. For this group, it is the aftermath of the two days of protest that really matters: how the protests dashed the potential of their local socio-political activism, their dream to change society from below, and their strategy for resisting the corrupt political regime. The protests also marked the start of a new era in which the political regime came to completely control the public and political spheres, and in which its neoliberal policies came to be less and less contested. The I 977 protests mark one of the last mass protests against the neoliberal policies initiated by Sadat after the end of the 1973 war. Meanwhile, the questions of what actually happened in the streets of Suez on I 8-i9 January 1977 and who was protesting remain unanswered.

\section{TRACES WITHOUT FACES: I 977 PROTESTS FOR PEOPLE WHO MARCHED IN THE STREETS OF SUEZ}

The paths of the demonstrations on I8-i9 January 1977 in Cairo and Alexandria have been drawn by numerous writers. ${ }^{38}$ Hence, I have also tried to draw the path of the demonstrations in Suez from the memories of

communists from all over Egypt were acquitted was not delivered until 1980. See Hussein AbdelRazik, Egypt in I 8 and I9 January. A Documentary Political Study, pp. I I I-I 24.

36. Ibid., p. I 2 .

37. Hazem Kandil, Soldiers, Spies, and Statesmen: Egypt's Road to Revolt (London, 2012),

pp. $363-364$.

38. See: AbdelRazik (1984); Saad (1988); El-Hamalawy (2001). 
my interlocutors in 2018, all of whom were middle-class Suezis who witnessed the protests but did not belong to any political organization at the time. Because my interlocutors were uncertain of where the protests in Suez began, the map in Figure 2 sketches the main streets they mentioned and buildings they remember as being burned in the city on I 8 January 1977.

According to their memories, the demonstrations mostly took place along the city's main north-south axis, Al Geish Street, extending from Al Mothalath neighbourhood in the north to Suez neighbourhood in the south (Figure 2). They also mentioned Orabi Street, a main thoroughfare in the central neighbourhood of Al Arba'in that connects to Al Mothalath, another neighbourhood where protest action took place. Ahmed, who was a government employee and the son of a well-known politically active local council member, but said he had not been politically active himself prior to the i 8 January 1977 protests, participated in the demonstrations that day, recalling that they eventually spread to most of the streets in Suez. Municipal buildings were attacked and even burnt, he recounted, as was the cultural centre that used to be the headquarters of the Socialist Union. This was located in a vibrant neighbourhood that included other public buildings and important Suez meeting places, such as the Department of Education. Ahmed mentioned that the protestors he marched with passed by the Department of Education and threw stones at it, and he recalled that employees in the building threw them back. It was not clear in the interview if he himself threw stones, but it was clear that, to this day, he does not know why the Department of Education was attacked.

The two main police stations in Suez - in Al Arba'in and Al Mothalath were also burnt during the protests. During my visit in 2018 , the first station was closed because it had also been burnt during the events of the 25 January $20 \mathrm{I}$ I revolution in the city. The $\mathrm{Al}$ Arba'in police station is a symbolic reference point in Suez because the Israelis hid there when they tried to occupy the city on 24 October 1973. The fida'yyin of the popular resistance managed to attack the station and it was this incident that prevented the Israelis from entering Suez, leading to their IOI-day siege of the city. That the police station in $\mathrm{Al}$ Arba'in is burnt every time there is an insurrection in the city highlights what Tilly calls the accumulation of repertoires of contention through memories. ${ }^{39}$

As the protesters traversed Suez's main street from north to south, travelling through the main three neighbourhoods of Suez, Al Arba'in, and Al Mothalath, they attacked and burnt not only the main public buildings, but also private properties belonging to people with close ties to the political regime. For the protesters, these buildings, even the private ones, were material representations of the political regime and its supporters. They were the main target of their anger against the regime's raising of prices on essential goods

39. Tilly, "Political Memories", p. 247. 


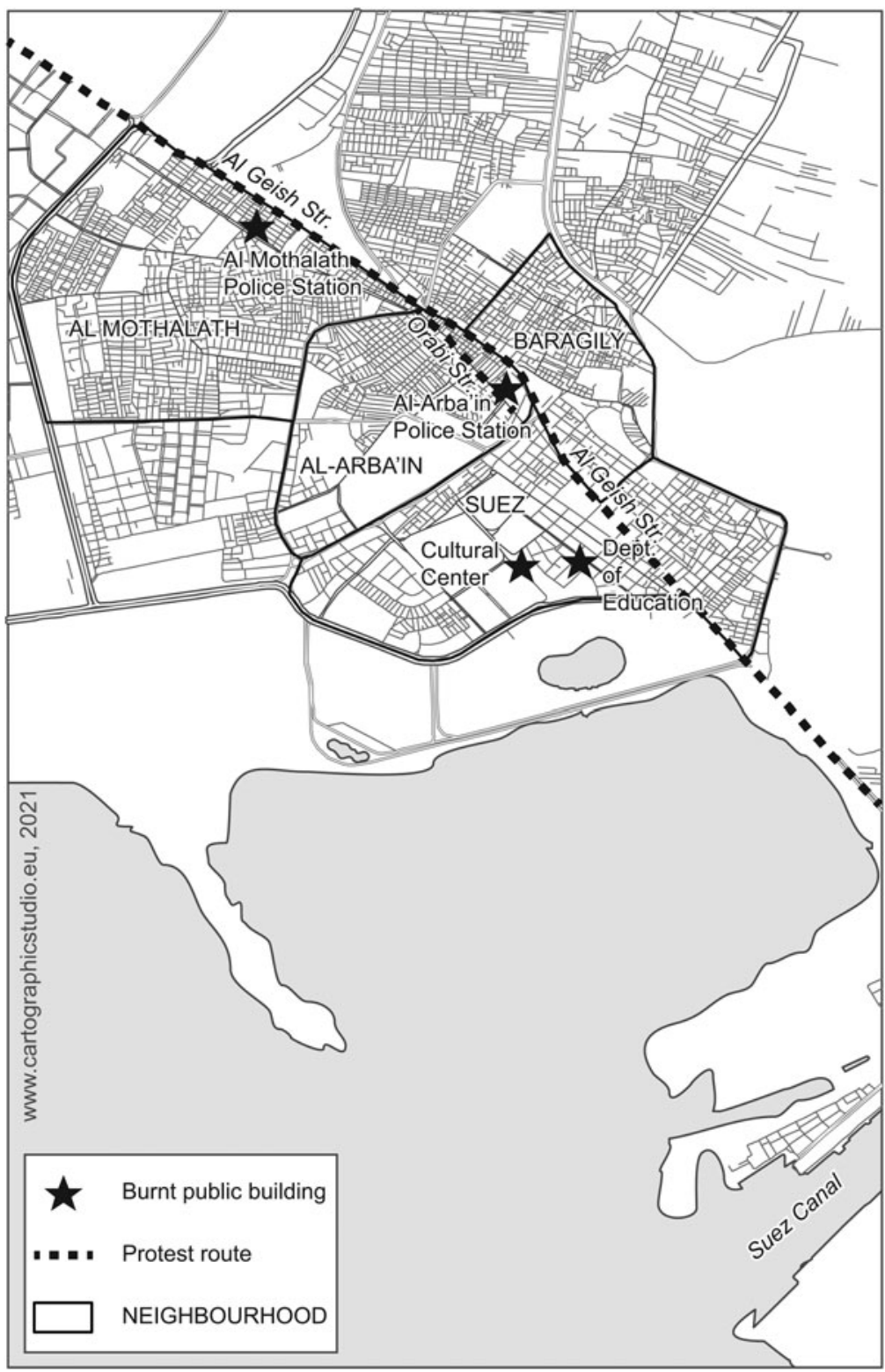

Figure 2. Map showing the sites of the 1977 protests in Suez, based on interviews.

and its switch to Nasserist welfare state policies. Allam, who recalled helping to calm down many of the protesters on this day, declared: 
The demonstrations were in Orabi Street. Haj Noor, who was a coffee shop owner and member of the Socialist Union, shot a young boy with his own revolver. I saw him shoot him and then run to his house, the same building as his coffee shop. I told the protestors that it was the owner of the coffee shop who had done it. I had barely finished speaking before they set the coffee shop on fire. How could they just burn it like that? This was the coffee shop we used to all sit in. I knew this guy and his children. Yes, the guy was a jerk and with the regime, but still. ${ }^{40}$

Amjad, currently a history teacher in Suez, who was in his teens during the demonstrations, recalled the same incident:

I 977 was very violent in Suez. [...] It was so out of control that it reached the level of sabotage: burning police stations like the one in Al Mothalath, and coffeeshops like the one owned by a famous Suez developer who was a member of Sadat's party. He faced off against the protesters and shot a gun in the air, and the people set the coffee shop he was sitting in on fire. There was also violence against buses and public services. ${ }^{4 \mathrm{I}}$

Allam, who had been active in the streets of Suez before the events of January I977, told me that he did not know the protesters at all, suggesting they were either people who had not previously been politically active, or had only recently come to the city. Ahmed told me he decided to join the protests without any prior organization because "everyone was in the streets". Though he recalled having been upset by the economic decisions, he insisted that they did not touch him personally, because he did not have financial responsibilities at that point in his life. Because Ahmed belonged to a social class of governmental employees and was in direct contact with the local leftist activists and intellectuals through his father, he does not consider himself to have been one of "the masses".

When I asked Amjad about who participated in the protests, he answered: "Ordinary people, ordinary citizens, young boys. The young people had a role in the spontaneity of the violence [...] many things were burnt." $\mathrm{He}$ also mentioned "those people at the margins of the streets, deprived of all privilege, so they would get engaged in any kind of violence against the symbols of authority". When I asked whether he meant secondary-school-age boys by "young people", he elaborated further:

There were also people with criminal records. This guy, Korea, was actually sentenced to five to fifteen years in prison. I saw him once when he got out of prison [...] Also, students and ordinary people in the streets, and people who just got swept up in the riots like workers from the cement factory. They used to catch the bus to their morning shift on our street, just across from us, around 6:30-6:45 in the morning. On that day, the people prevented the buses from moving and so the workers got engaged..$^{42}$

40. Interview with Allam, Suez, 22 November 2018.

4I. Interview with Amjad, Suez, 7 November 2018.

42. Ibid. 
In mentioning the spontaneous participation of marginalized people and those who were in the streets - young people and those who were not previously politicized - he echoes the findings of most of the literature on the 1977 events, citing the participation of "the masses" without faces. Amjad's most interesting remark, however, concerns the fact that the person named "Korea" was sentenced to between five and fifteen years in prison for his participation in the riots. While I could find no more details about the criminal record of "Korea" specifically, we do know that, after the protests, around 2,000 people were arrested across Egypt and indicted on accusations related to their participation or potential participation in the protests. ${ }^{43}$

In a long critical analysis of the 1977 uprising published in $20 \mathrm{I}$ I, communist writer Adel Al A'amry points out that there was significant discrimination in how the state dealt with these "masses" in the judicial system..${ }^{44}$ In a verdict celebrated by the Egyptian left as a victory, the communists and leftists who were chased by the state and accused of being responsible for the protests and their ensuing violence were cleared of all the charges against them. However, those others charged in relation to participation in the riots those who had not previously been politically active and did not belong to leftist political parties or movements - were convicted and often sentenced to years in prison, just like "Korea". 45

Al A'amry criticizes the leftist intellectuals for their reaction to the 1977 protests and their aftermath. ${ }^{46}$ In refuting the charges against them, the leftists tried to prove that they had nothing to do with the violence that occurred during the protests, or they argued that the protests had started off as non-violent, only changing course when government-ordered "intruders" showed up and began initiating violent acts. ${ }^{47}$ Either way, they maintained a discourse that those who set things on fire were "not us". The same tone arose when my leftist interlocutors in Suez remembered the protests. They claimed they had not known about the protests beforehand. They said they did not participate in them, that they just observed, and that they tried to calm down the other protesters, urging them not to burn or sabotage. Those who were in the streets, they said, were "not us". It is here that the process appears of making the masses who participated in these protests absent or as if they did not exist. The taghyib of the masses who participated in these protests is not engineered by the State authorities only but also by the leftists who were part of the opposition at the time.

43. Adel Al A'amry, "Different Reading of 18-19 January 1977 Uprising”, AHewar Al Motamadin, 20II. Available at: http://www.ahewar.org/debat/show.art.asp?aid=260472; last accessed 19 December 2020.

44. Ibid.

45. Ibid.

46. Ibid.

47. Hussein AbdelRazik, Misr fi I 8 wa I9 yanayir. Dirasa siyasiyya watha’iqiyya, p. I I 2. 
Al A'amry argues that those who participated in the spontaneous protests of 1977 used violence as a means to express their anger and dissatisfaction, suggesting that it comprised an important part of their repertoire of action. ${ }^{8}$ The fact that Suez was still under construction and just out of a war did not prevent people from adopting this same repertoire of action. The protests on the streets of Suez and other Egyptian cities led Sadat to call in the army to restore order, and ultimately caused him to revoke the austerity measures. Today, we cannot speak with those only remembered as "masses", nor access their personal narratives. We may get to know the traces of those who were present, but not their faces and their voices. They are present in memories of the event, but as ghosts. The memory of these people and what they did on I 8-19 January in Suez still haunts the city, warning against chaos, but also reaffirming the city's legacy of resistance.

\section{MEMORY OF FEAR AND RESISTANCE: I977 PROTESTS AS REMEMBERED FROM HOMES IN SUEZ}

When remembering the 1977 protests in Suez, both of my two interlocutors who witnessed the protests from their "homes" emphasized a fear of the unknown, especially in the context of Suez as a city in the process of finding its way back to normality at the time. In 1977 , Zinat was a young woman who had just returned to Suez after seven years of forced migration and was working as a teacher. When I asked her if she remembered what happened in 1977 , she immediately answered: "Yes, the uprising of the thieves." This was the term used by Sadat in his speech in front of the parliament after the protests. In her memory, the protesters were clearly "the other", not real Suezis, but those who came from other governorates to rebuild and reconstruct the city. For her, "real" Suezis, those who had lived through the war and the city's destruction, would not use violence when protesting. At the same time, however, she made it clear that she understood the people were suffering from the rises in prices and acknowledged that the economic situation was hard. When the protests broke out, she was at school, teaching, but went home and stayed there. As she remembers:

Yes, we were afraid, afraid and we stayed home. The city was already destroyed. Moreover, those who were active were not peaceful. Whoever was out, was destroying things. They were not protests demanding that the president take back his decision because we are tired or whatever. They were destroying the country, just as on the 25 th of January [20II], many things were destroyed in the town, here in Suez, I swear to God. I was remembering today when you called

48. Al A'amry, "Different Reading of I 8-I9 January I 977 Uprising”. 
me, how they looted Omar Effendi and the cooperatives. ${ }^{49}$ [In I 977 ...] they also broke into and looted cooperatives. By the way, these are not the people of Suez, but people from other nationalities, or how do they call it, tribes? Something like tribes - those who come from Sohag or from Qena, not locals. ${ }^{\circ}$ No, the people of the city cared about it. I mean, the people of Suez who lived through the war and were touched by it.

Moreover, when Suez was opened in 1974, they considered it to be a second Libya, I swear to God. ${ }^{\text {II }}$ For those who used to come to Suez to work in the construction sector or the companies, they came as if they were going to Libya. For them, it was a source of income and investment. The city was full of people who came to rebuild and reconstruct. Most of them were foreigners, not originally from Suez, not Suezis, I swear to God, because it happened in the area of Al Arba'in. ${ }^{52}$

This excerpt from the interview shows that her memory of the 1977 protests is associated with fear. Zinat stayed at home to avoid the chaos and any potential attacks. She mentions the robberies that happened and, most importantly, she compares events with the 25 January 20 I I protests. This is also how the father of my interlocutor Amjad, who was a teenager in 1977 and witnessed the events from his balcony, reacted to the protests. Amjad's father had been a communist in his younger years, and in the 1950s had even been arrested. In 1977, however, Amjad remembers that his father, then a government employee, was sceptical of the protests and prevented his teenage son from going out into the streets, even from going to school, while he himself returned home from work early.

Owing to Amjad's education, reading, and overall influence from leftist ideology, including his activism later in life, his memory of the 1977 events differed significantly from Zinat. Though he also compared the 1977 protests with the 25 January 20 I I uprising, he saw both as episodes of resistance, arguing that I 977 was a rehearsal for the 20 I I protests. In the latter, he noted, the police station in $\mathrm{Al}$ Arba'in was also burnt by the protesters, and the demonstrations took place in almost the same streets. In his analysis of the reasons the 1977 protests broke out in Suez, Amjad stressed the specificity of Suez as a city of resistance. He cited the city's resistance to the Israelis during their IOI-day siege of the city three years prior to the 1977 Bread Riots. He also recalled the presence

49. Omar Effendi is a well-known department store chain in Egypt. Cooperatives were statesponsored markets where the people could get essential goods supported by the State.

50. Sohag and Qena are governorates in Upper Egypt, where harsh living conditions often forced people to emigrate to seek work in big cities. Most inhabitants of Suez have roots in Upper Egypt, which was the case even before the forced migration in 1967 . However, this rural-urban exodus intensified after 1975 due to the reconstruction work in the city.

5I. In the I970s, Libya was a prime destination country for Egyptians emigrating to find work, much like the Gulf states. Comparing Suez to Libya emphasizes the city's new role as a destination for job seekers from Upper Egypt.

52. The neighborhood of Arba'in was home to many of the city's immigrants. Interview with Zinat, Suez, 4 December 2018. 
of a strong workers' movement in Suez, ${ }^{53}$ the lack of infrastructure, and the high expectations that Suezis had after the war, based on the government's promises. For him, the memory of 1977 in Suez comprises one episode in a long tradition of Suezi resistance: from the city's resistance to English occupation and Israeli invasion, to its resistance in the 25 January 20 I I revolution.

Several months after my conversation with Amjad, in a statement published in a 2019 article for the Egyptian online news outlet Mada Masr, ${ }^{54}$ an intellectual from Suez extended the historical trajectory of resistance in the city to include the protest episode that broke out on 19-20 September $2019 .{ }^{55} \mathrm{He}$ declared:

The Nasserist regime founded in the city what we call the 'popular university' and a second Socialist Institute [a cultural organization related to the Socialist Union], which have contributed to the continuity of political life in the city. [Suez] has known politics before, through the activities of political movements like the communists, the Muslim Brotherhood, and the Misr Al Fattab [party]. This continued even under Mubarak, through the solidarity campaigns with the Lebanese and Palestinian people during the Israeli invasion [of Lebanon] in $1982 .{ }^{56}$

Once again, in the wave of protests in September 2019, Suez was in the vanguard. It was one of the cities where the protests were the most violent and the streets were full of people; many insurrections took place, especially around the Al-Arba'in Mosque, and dozens of people were arrested. The previously mentioned Mada Masr article suggests that Suez has a legacy of resistance that always leads the city and its population to be at the vanguard of political opposition movements in Egypt, past and present. Mostafa, the teacher mentioned in $\mathrm{Al}$ Ahram, also presented a similar argument:

Suez is a city that went beyond the line of political movements in Egypt [...] There has always been a general line in Egyptian society, a certain limit, and we went beyond this limit. We became heard to the authorities in Egypt [Cairo]. That's why, in the events of January [1977], the authorities were violent and exercised an excessive level of brutality in following and capturing us [...] To this day, Suez constitutes a red line. For leftists and those who know, it is communist [...], and for those who only have a general idea, it is in the opposition. Suez is a city always in the opposition.

53. For more information, see Joel Beinin and Zachary Lockman, Workers on the Nile: Nationalism, Communism, Islam, and the Egyptian Working Class, I882-I954 (Princeton, NJ, 1987).

54. Beesan Kassab, “An Entry to Understand What Happened in Suez", Mada Masr, 2019. Available at: https://tinyurl.com/I I 2 I 25 m; last accessed is February 202 I.

55. A wave of protests broke out in many Egyptian cities on 19-20 September after a series of videos by an Egyptian real estate developer revealed corrupt practices by the Egyptian army. The protests in Suez lasted for two to three days and included many clashes with the police.

56. Kassab, "An Entry to Understand What Happened in Suez". 
In these reflections, the 1977 protests in Suez are remembered as one episode in a longer tradition of protest and opposition to the authorities. Kahled Fahmy (20I5) argues that Egyptians have always protested against occupation and repression, situating the 25 January $20 \mathrm{I}$ I uprising as just one episode in a long history of Egyptian popular resistance. ${ }^{57}$ This argument somewhat romanticizes contention, however, as it fails to consider the different motivations of those who were involved in each episode. Suezis who participated in the 1977 Bread Riots have not had the chance to convey their personal motivations for taking to the streets and expressing their anger at the government. At the time, they may not have thought about the protests as an episode in a long line of resistance; they may have only seen them as a means to express their anger at policies that affected their everyday lives. Thus, they may have not given the same answers or interpretations of the protests as those that were advanced by intellectuals and political activists after the fact.

\section{CONCLUSION}

The three memory fragments presented in this article help us to understand how middle-class Suezis remember the 1977 Bread Riots in Suez, offering an alternative vantage point for viewing the memories and meaning of this significant event in Egyptian history from the one that is available in the existing and largely Cairo-centric literature on the protests. Then a city just returning from nearly a decade of war and forced migration, Suez was still in the process of reconstruction in January 1977, and its inhabitants held expectations for a better life ahead. The first fragment shows the disappointment of a group of young people who were politically engaged and full of hope after the war. Crucially, it shows how remembering the 1977 protests for this group was not primarily about the protests themselves, meaning what happened on the streets. Rather, their memory of the protests encompassed a much broader temporality than the two days of unrest in January 1977 and centred on the fact that their political activism was being forced to end. The broad criminalization of membership in leftist organizations in the aftermath of the protests, rather than criminalization of actual participation in the events, abruptly dashed their dreams and significantly altered their political and private trajectories.

The second fragment engages with the unknown traces and faces of people who marched in the streets of Suez through the memories of my interlocutors, one who participated in the protests and several who witnessed them, but none of whom had been active in organized politics prior to the event. Owing to the difficulty of conducting fieldwork and accessing archives in Egypt, the main 
participants in the protests are not accessible; rather, they are actively absent. They exist as ghosts in my interlocutors' memories. Through these memories and the scant traces left behind in newspapers, articles, and books over the years, we can feel and see their effects, but we cannot see them. The people who took to the streets in Suez and across Egypt in January 1977 made the government revoke its decision to impose austerity measures, but today they remain the unknown, the extras, the "other". They only exist in memory as the "masses": the marginalized; the street vendors; day-labourers; workers; and perhaps also foreign migrants to the city who came seeking opportunities after the war.

Finally, the third fragment explores the themes of fear and resistance that predominate in the memories of two interlocutors who witnessed the 1977 protests from their homes in Suez. For the other interlocutor, however, it affirms and further feeds what he views to be a positive legacy of Suez as a city always at the vanguard of oppositional movements and historic progress in Egypt: an esteemed city of resistance. For him and other Suezis documented in media and scholarship, the 1977 Bread Riots represent one revolutionary episode in a broader, ongoing emancipatory trajectory in contemporary Egyptian history.

This article's exploration of memory and the 1977 Bread Riots in Suez has shown that the 1977 protests were a moment in which the absent became present through their actions, sabotage, and physical presence on the streets. ${ }^{58}$ Since the actual events, however, they have been subjected to a structured and multilayered process of taghyib, starting with their representation in the media, but also including their unequal treatment by the country's judicial system, and even the process of remembering them. Today, they once again appear only as nameless, faceless people, as the "other", as ghosts.

58. Yassin Al Haj Saleh, الألنفكبر †إلصالح†أفكار †:ائبين†أصوات (Voices of the Absent: Ideas Towards the Renovation of Thought). 